\title{
A Review of Continuous Relevance of the Traditional Methods of Dispute Resolution Mechanism in Southeast of Nigeria
}

\author{
Igwe Onyebuchi Igwe*, Kevin Onwuka Udude, Ogah Chinyere Constance \\ Faculty of Law, Ebonyi State University, Abakaliki, Nigeria \\ Email: ^igwelaw2010@gmail.com
}

How to cite this paper: Igwe, I. O., Udude, K. O., \& Constance, O. C. (2020). A Review of Continuous Relevance of the Traditional Methods of Dispute Resolution Mechanism in Southeast of Nigeria. Beijing Law Review, 11, 34-42.

https://doi.org/10.4236/blr.2020.111003

Received: September 29, 2019

Accepted: January 7, 2020

Published: January 10, 2020

Copyright $\odot 2020$ by author(s) and Scientific Research Publishing Inc. This work is licensed under the Creative Commons Attribution International License (CC BY 4.0).

http://creativecommons.org/licenses/by/4.0/

\begin{abstract}
Dispute Resolution method like culture is a way of life. Every method is special to people based on their value orientation and the desire to preserve social norms. Before the advent of colonial rule and regular court system to $\mathrm{Ni}-$ geria, Southeast of Nigeria had a system of dispute resolution mechanism adjudged to be simple, inexpensive and friendly. Resolutions of disputes were handled by family heads, village heads, elders, kindred, age grade, council of elders, chiefs, chief priests, judicial council among others. The practice was very strong until it was watered-down by the advent of colonial administration and regular court system. The end product was the introduction of western methods of dispute resolution in Nigeria which have remained in constant battle with the tradition of the people Southeast of Nigeria. This work became imperative in view of strong calls to return to indigenous methods of dispute resolution in Southeast Nigeria. The aim of this is to ensure that parties to a dispute amicably resolve their differences outside the normal courtroom processes. This paper was commenced by investigating into various traditional means of dispute resolution in Southeast.
\end{abstract}

\section{Keywords}

Tradition, Dispute Resolution, Southeast, Nigeria

\section{Introduction}

Southeast ${ }^{1}$ of Nigeria is a geographical zone predominantly occupied by Igbo speaking people. It presently comprises the states of Abia, Anambra, Ebonyi, Enugu and Imo. Available evidence points to the fact that prior to the advent of western civilisation and adjudicatory system to Nigeria, various tribes indigen-

${ }^{1}$ Southeasterners are also called Ndigbo in Nigeria. 
ous to Nigeria had traditional methods of dispute resolution mechanisms anchored on their native law and customs. Dispute according to Black's Law Dictionary, (2009) is "A conflict or controversy especially one that has given rise to a particular lawsuit". ${ }^{2}$ Magaji (2016) noted that "Disputes are generally inevitable and in the fast paced time conscious world, the protracted dispute resolution by trial may not always be the most desirable means to achieving justice". ${ }^{3}$ Dispute resolution mechanism may be linked to a procedure for resolving grievances among persons following a laid down rules and regulations.

One refers to traditional method of dispute resolution if the process of complaint, adjudication and decision is initiated and concluded in accordance to native law and custom of the people concerned. In Okereke v. Nwankwo ${ }^{4}$ the court defined a traditional method of dispute resolution as "arbitration in dispute founded on the voluntary submission of the parties to the decision of the arbitrators who are either the chiefs or elders of the community". Every traditional method of dispute resolution is peculiar to people as a result of long usage that has influenced their way of life. According to Akhigbe et al. (2014), "There existed a firmly rooted customary adjudicatory system in Nigeria before the coming of the colonial masters". ${ }^{5}$ In the case of Okpuruwu v. Okpokam ${ }^{6}$ Oguntade JCA (as he then was) acknowledged that: "in the pre-colonial times and before the advent of the regular court, our people (Nigerians) had a simple and inexpensive way of adjudicating over disputes between them".

In Southeast Nigeria, there is a traditionally rooted method of dispute resolution before the colonial rule in Nigeria. The people of Southeast of Nigeria have for a long time resolved disputes among their kith and kin outside the normal court rooms and maintained harmonious relationships over the years before the western interference. They referred disputes to the family head, elders, chiefs, kings among others. In Southeast of Nigeria, traditional method of dispute resolution is based on decisions through discussion and consensus rather than argumentation of trained legal personnel often witnessed in court, Igwe (2019). ${ }^{7}$ The practice has over the years become strongly embedded in the system that ${ }^{2}$ B.A. Garner (2009), Black's Law Dictionary ninth ed (Dallas: West Publishing Co.,) p. 540.

${ }^{3}$ H.S Magaji. A Legal Analysis of ADR and the Civil Justice System in Nigeria. Rule of Law, Governance Dispute Resolution and Contemporary Legal Issues in Nigeria. (Zaria: ABU Press, 2016) p. 86. ${ }^{4}$ [2003] 9 NWLR (Pt. 826) p. 592.

${ }^{5}$ E.E Akhigbe, A Adekanle, P.F Oamen, A.A Tijani, M.F Idahosa and M.E Nwocha, "100 Years of Customary Law and Disputes Settlement in Nigeria-A Comment." Law in Nigeria @ 100 Reviewing the Past, Projecting the Future, Proceedings of the $47^{\text {th }}$ Annual Conference of the Nigerian Association of Law Teachers (NALT) held on $2^{\text {nd }}-6^{\text {th }}$ June, 2014 at Ebonyi State University Abakaliki-Nigeria.

${ }^{6}$ [1988] 4 NWLR (Pt. 90) 544 at 580. In another development, J.K Gadzama noted that "arbitration is a means of settling dispute with various indigenous communities in Nigeria and the whole of Africa before the invasion of Africa and the introduction of the English legal system of court litigation as a means of settlement of disputes. J.K Gadzama, Development and Practice of ADR and Arbitration in Nigeria under the Subtitle inception of Arbitration in Nigeria" being a paper presented at the NBA Annual Conference, Abuja, 2004. E.C Onyeozili and O.N.I Ebbe (2012), "Social Control in Pre-colonial Igboland of Nigeria", 6 \#S 1 \& 2 African Journal of Criminology and Justice Studies, 33-34.

${ }^{7}$ I.O Igwe "Legal Practitioners in Public Service and the Unresolved Issue of Engaging in Private Legal Practice: An Appraisal” in Amari Omaka, M.E Nwocha and Enya Onya (eds) Law \& Justice Dispensation for Social Progress and Sustainable Development; A Festschrift in Honour of Hon. Justice Eze Udu, Abakaliki: Faculty of Law, Ebonyi State University, p. 253. 
they survived today as custom.

The purpose of this paper is to investigate into the methods of dispute resolution mechanisms known to indigenous people of the Southeast of Nigeria. This is with a view to identifying why the traditional methods of dispute resolution mechanism in the Southeast have continued to be relevant in the administration of justice in Nigeria.

\section{Traditional Methods of Dispute Resolution in Southeast Nigeria}

In Southeast Nigeria, the court of first instance is the parent(s). Parents have the responsibility of settling minor disputes that arose among the children and wives. In most cases, the head of the family may convene a court composed of the wives and children who would be there to witness the judgment aimed at burying the dispute and correction of the offending member of the family. ${ }^{8}$ Other level of court of first instance in traditional setting of Southeast Nigeria includes the council of elders. The council of elders handle more serious dispute among members of village or community. Cases usually referred to the council of elders include serious land dispute or serious offences otherwise called public offences or abominable offences ( $a r u)$. The person accused of committing public offence is tried before the council of elders who usually sit in holy place like ancestral home, playground or market place.

Ndi Eze, Ndi Ichie, Isiuke otherwise called the judicial council among others serves as court of appeal in the traditional dispute resolution mechanism in Southeast Nigeria and at the same time has original jurisdiction in dispute involving clans or villages. Memberships of judicial council are drawn from titleholders who are considered righteous men among members of clans that make up the community. ${ }^{9}$ The Chief Priest Court served as the Supreme Court in the traditional dispute resolution mechanism Southeast Nigeria. The Chief Court handles most difficult and serious civil and criminal cases. The verdict of the Chief Priest Court is final and it is believed to rain calamity on the guilty person. ${ }^{10}$

The traditional dispute resolution mechanism in Southeast Nigeria entrenches the principles of fair hearing in case disposal processes. Parties to a dispute are allowed to present their cases and call witness or witnesses where the need arose. Decisions in matters are taken openly and in the presence of the parties, members of their family, village or community.

Truth remained the watchword in traditional dispute resolution mechanism in in Southeast Nigeria. Both the disputants and the arbitrators would be ex-

${ }^{8}$ E.C Onyeozili and O.N.I Ebbe (2012) Social Control in Precolonial Igboland of Nigeria. African Journal of Criminolgy and Justice Studies: AJCJS, Vol. 6, \#s1 \&2, 36.

${ }^{9}$ Kindred units, age grades, village heads, communities, masquerade societies, diviners, oracles. In Pre-colonial Igbo time the following famous oracles existed.

${ }^{10} \mathrm{Among}$ the power deities in Igboland include They were: Ibini Ukpabe of Aro-Chukw in Abia State, Igwe-ka-Ala of Umunoha, Kamalu of Ozuzu, Mkpokiti Obirikete of Umunze, Haba of Agulu, Igwele of Uburu, Nte Ofine of Echara, Ali Igbudu, Nkwo Ameka, Arishi Okpuzu, Juju of Okija, Mkpuma Ebonyi among others. 
pected to be truthful. According to Theresa (2014), it is the firm belief that the "presence of the ancestral forces is a factor; some may collapse or be forced to say the truth because of the ancestral forces". ${ }^{11}$ In cases where it is difficult to ascertain the truth especially where either the identity of the offender is in doubt or it is very difficult to resolve the facts in issue, instruments like oath taking, divination and trial by ordeal are usually employed.

\section{1) Oath Taking}

Oath is "A solemn declaration, accompanied by a swearing to God or a revered person or thing that one's statement is true..."12 Garner (1999). The person making the Oath wholly invites punishment upon himself if the statement turns out to be false. Oath taking is a serious instrument use in dispute resolutions in Southeast Nigeria. It is used in serious disputes because of its grave consequences. Items like kola nut, sand, cock, egg, symbol of shrine (juju) among others are use in Oath taking process in Southeast Nigeria. Women and children are exempted from Oath taking in Southeast Nigeria because of the belief that they are not knowledgeable enough to understand the implication of Oath taking, Mbiti (1969). ${ }^{13}$ This aspect of Igbo system of justice administration is captured in the rule of evidence in regular courts. For this purpose, section 205 of the Evidence Act, 2011 also recognises the importance of oath taking by requiring all oral evidence in court to be given upon oath of affirmation. ${ }^{14}$ Oath taking in Southeast Nigeria has received judicial blessings in cases of Onyenge \& 2Ors v. Ebere \& 2Ors, ${ }^{15}$ and Oparaji v. Ohanu, Njoku v Ekeocha \& Anor ${ }^{16}$ and Ojibah v. Ojibah ${ }^{17}$.

\section{2) Divination}

Divination is derived from Latin word "divinire" which means to foresee, to be inspired by gods. It is an attempt to gain insight into a question or situation by way of occult or ritual processes. According to the New Webster Dictionary (1995), divination is "the art of telling of the future or the unknown by supernatural means". ${ }^{18}$ In Southeast Nigeria, it is not out of place among the indigenous people to invite a diviner to unravel some mysteries in family, village or the community, Akhigbe et al. (2014). ${ }^{19}$ In a situation where crime is committed and the identity of the offender is in doubt, diviners are always consulted to unravel the offender. Diviners are believed to be middlemen between the living and the

\footnotetext{
${ }^{11}$ A.A Theresa, "Methods of Conflict Resolution in African Traditional Society" African Research Review an International Multidisciplinary Journal, Ethiopia Vol. 8 (2), Serial No. 33, April, 2014: 138-157. https://doi.org/10.4314/afrrev.v8i2.9

${ }^{12}$ B.A Garner, Black's Law Dictionary Seventh Edition (USA: West Group St. Paul Minn, 1999) p.1099.

${ }^{13}$ J.S Mbiti African Religion and Philosophy (London: Heinemann, 1969) p. 85.

${ }^{14}$ Section 208 of the Evidence Act 2011 permit the court in some circumstances to receive evidence though not on oath from a witness base on the religious belief.

${ }^{15}$ [2004]All FWLR (Pt. 219) 98.

${ }^{16}[1972] 2$ ECSLR (Pt. 1) 199.

${ }^{17}$ [1991] 5 NWLR (Pt. 191) 296, 314.

${ }^{18}$ The New Webster Dictionary of the English Language International Edition (New York: Lexicon International-Publisher Guild Group, 1995) p. 275.

${ }^{19}$ E.E Akhigbe, A Adekanle, P.F Oamen, A.A Tijani, M.F Idahosa and M.E Nwocha, op cit, p. 480.
} 
dead. Southeasterners believe strongly in the potent of their gods and ancestors. It is expected that after incantations, a diviner would tell the consultants who the culprit of an offence was or should be able to trace the missing article. The fear of being taken to a diviner often propels the suspect to say the truth. Divination is a strong instrument of traditional dispute resolutions in Southeast Nigeria.

\section{3) Trial by Ordeal}

Trial by ordeal is a traditional method of subjecting a suspect to physical test in order to ascertain his guilt or innocence. Black's Law Dictionary (1999) defines ordeal as "A primitive form of trial in which an accused person was subjected to a dangerous or painful physical test, the result being considered a divine revelation of the person's guilt or innocence". ${ }^{20}$ Trial by ordeal is one of the instruments of traditional dispute resolution in Southeast Nigeria.

The above instruments of traditional dispute resolutions were among the strongest means of social control employed in Southeast Nigeria. "This was prefixed on the belief that if human attempts at getting at the truth failed, at least the unseen forces would not err' Adewoye (1977). ${ }^{21}$ The instruments worked very effectively in pre-colonial Southeast Nigeria and if they are allowed to take their proper place again, dispute resolutions and social control will be easier in Nigeria particular in the Southeast.

\section{Invasion of Traditional Methods of Dispute Resolutions in Southeast by Regular Court System}

The introduction of the regular court system in Nigeria by the British colonist was first propelled by the desire of the British merchants to enforce the payment of debts by indigenous merchants. This was kicked-off by the appointment of British consul in 1949 to regulate lawful trade between British merchants and indigenous merchants in the ports of Benin, Bimbia, Bonny, Brass, New and Old Calabar, Dahomey and Cameron, Obilade $(1979)^{22}$ which later formed part of Nigeria. ${ }^{23}$ This was followed by the establishment of consular court in 1862 that dealt with trade dispute between indigenous merchants and British merchants. Later the merchants established court of equity to help regulate their business transactions in good conscience. The consul and equity courts were under the control of consul.

By 1863, the British Administration introduced English law into the colony of Lagos with effect from $4^{\text {th }}$ March 1863 . By the above introduction, the first Supreme Court Ordinance was enacted in the same 1863 to deal with both civil and criminal matters brought before it within the colony under jurisdiction. ${ }^{24}$ In 1876, a Supreme Court Ordinance was enacted for the colony of Lagos and the territories where British Government had jurisdiction. 1876 Supreme Court Or${ }^{20}$ Black's Law Dictionary, op cit p. 1123.

${ }^{21}$ O. Adewoye, The Judicial System in Southern Nigeria (New Jersey: Atlantic Highlands Humanities Press Inc 1977) p.8.

${ }^{22}$ A. O Obilade, Nigerian Legal System (Ibadan: Spectrum Law Publishing, 1979) p. 18.

${ }^{23}$ Ibid.

${ }^{24}$ Ibid. 
dinance empowered the court to apply the common law of England, the doctrine of equity and statutes of general application in force in England on $4^{\text {th }}$ July, 1874 in administration of justice in colony of Lagos and the territories where British Government had jurisdiction.

The progressive incursion of the British into the hinterland necessitated the introduction of tripartite test of validity before the application of customary law in justice administration in Nigeria. For this purpose, for a customary law to be applicable, such custom must not be repugnant to natural justice, equity and good conscience; nor incompatible with written law for the time being in force; nor be against public policy. Obilade (1979) noted that by the subjecting local laws and customs to the test of repugnancy to natural justice, equity and good conscience, and incompatibility test with written law, the British Administration relegated local laws and customs. ${ }^{25}$ With the amalgamation of the southern and northern protectorates as an entity called Nigeria in 1914, the Criminal Code Act of 1916 was drafted for the south while the Penal Code Act of 1862 was made applicable to the north. The above laws vested criminal offences in the exclusive reserve of the state with the technical and rigorous method of proof beyond reasonable doubt associated with criminal offences. This was followed by different rules introduced to regulate civil proceeding in courts in Nigerian.

In order to ensure that trial by jury known to traditional Southeast Nigeria is watered-down, trial by single judge was introduced in superior court of first instance like state high courts and Federal high courts in Nigeria. The end product is that justice is now for those who can afford the cost of litigation in Nigeria.

Despite the injury caused on administration of justice system in Nigeria by the colonial rule, the people of Southeast of Nigeria have began to realise that traditional methods of dispute resolution is the best approach to administration of justice in Nigerian soil. For instance, until now, emphasis on Nigerian criminal justice system was purely placed on punishment of an offender through imprisonment or payment of fines to the state. This is in view of Section 2 of the Criminal Code $\mathrm{Act}^{26}$ which defines offence ${ }^{27}$ as "act or omission which renders the person doing the act or making the omission liable to punishment under the Code". By this provision, Criminal Code Act pushes offence to the domain of state control and ownership. The implication is that state controls the prosecution of crimes and the individual wronged by the accused person cannot stop or continue the trial of the accused person in the absence of the state. However, the recent trend in dispute resolution globally is on restorative justice measure ${ }^{28}$ aimed at victim-offender mediation, family group conferencing, community mediation among others. For this purpose, restorative justice encompasses award of costs, compensation, damages, restitution among others. This is in line

\footnotetext{
${ }^{25}$ Ibid, p.19.

${ }^{26}$ It should be noted that Criminal Code Act was drafted in 1916 based on culture of colonial master and their intimidating spirit that ruled their administration.

${ }^{27}$ Offence is used interchangeable with crime in Criminal Code Act.

${ }^{28}$ Nigerian Correctional Service Act, Section 37 (1) (d).
} 
with the traditional methods of dispute resolution indigenous to people of Southeast of Nigeria.

Okafor et al. (2018) acknowledge that traditional method of dispute resolution is "indispensible to the maintenance of the corporate cohesiveness of our people, especially or Ibo ${ }^{29}$ people" ${ }^{30}$ It is the view of the authors that considering the cost implication of the present justice system on the state, the litigants and tax payers, a reinvigoration of traditional methods of dispute resolution indigenous to people of Southeast of Nigeria would serve the need of the society and litigants. For this purpose the following targets would be achieved to wit.

1) The psychological effects created upon litigants in the environment of regular court system will be reduced especially when disputes of trivial nature are settled out of the court room.

2) Friendly settlement of dispute among the parties will be reinvigorated. This is in line with the traditional methods of dispute resolution in Southeast of Nigeria as people are seen exchanging pleasantries, sharing drinks, food and kolanuts together at the end of dispute resolution instead of the laugh/cry situation normally created at the end of court's judgment in cases.

3) Traditional methods of dispute resolution in Southeast of Nigeria saves the time of the parties to dispute since technicalities involved in court proceedings are not always there.

4) The victim of the crime in criminal cases may benefit since part of traditional methods of dispute resolution in Southeast of Nigeria require an offender to pay compensation or damages to the person offended or restitute the property stolen or damaged among others.

\section{Research Method}

In order to appreciate the topic under discourse, the research adopted a doctrinal research method. By this method, a careful review of various methods of dispute resolutions in the Southeast of Nigeria were carried out with a view to identifying why they have continued to be relevant in the administration of justice in Nigeria toady. This was achieved by utilising primary and secondary sources of materials such as statutes, case laws, textbooks and journal articles.

\section{Findings}

The research found that one of the major challenges to the advancement of traditional method of dispute resolution in the Southeast of Nigeria is the introduction of the tripartite validity test by the received English law as a basis of the application of customary laws in Nigeria. At present, for a custom to be applicable in settling dispute in Nigeria, such a custom must not be repugnant to natural justice, equity and good conscience; or incompatible with written law for the time being in force; nor be against public policy. Obilade (1979) noted that by

${ }^{29}$ I.A Okafor et al. Avoiding Conflict Escalation and Total Implosion. Alternative Dispute Resolution Law Journal Vol. 2, No. 1. (Enugu: Jukel Prints Ltd., 2018) p. 76.

${ }^{30}$ Ibo are the people predominantly occupying the Southeast part of Nigeria. 
subjecting native law and custom to the test of repugnancy to natural justice, equity and good conscience, and incompatible with written law, the British Administration relegated native law and custom. ${ }^{31}$

Again, in the present day where truth has become a scarce commodity in Nigeria, it is obvious that most of the elders, chiefs, village heads among others are likely to be bias in their decision because of corruption and favouritism that have permeated all sectors of Nigerian lives.

Another challenge to the advancement of traditional method of dispute resolution mechanism in Southeast is adopt of Western standard of lives by most people of the Southeast Nigeria. Today, migration to urban areas, disrespect to elders, infiltration of traditional arrangement by politics and cases people abandoning their homes for years in search of better standard of living in developed cities have actually acted as disconnect between the people of the Southeast $\mathrm{Ni}$ geria and their tradition.

The outcome of the above discussion is that English styles of justice delivery imported into Nigeria have not served the need of the people of Southeast of Nigeria. Therefore, time has come to return to method of dispute resolution indigenous to people of Southeast of Nigeria if the desired peace must return to Southeast of Nigeria.

\section{Conclusion}

What emerges from the discussion above is that before the advent of western civilization and court system to Nigeria, various tribes indigenous to Nigeria had their traditional methods of dispute resolution anchored on their native law and customs. In the Southeast of Nigeria, disputes were referred to family heads, elders, village or community heads and other various units charged with the responsibilities for settling disputes among their kilt and kens.

Traditionally, the people of the Southeast employed instruments like oath taking, divination and trial by ordeal to resolve cases especially where the truth or the identity of the party involved cannot be easily ascertained. The above traditional methods have continued to be relevant among the people of the Southeast of Nigeria, even though the strongholds of the same have been watered-down by the intrusion of western methods of dispute resolution into Nigerian legal system.

It is based on the above that this paper calls for the reinvigoration of the traditional methods of dispute resolution mechanisms in the Southeast of Nigeria as the basis of achieving lasting peace and tranquility among the people. This is indispensable if the corporate cohesiveness among the people of Southeast of Nigeria must be maintained.

\section{Conflicts of Interest}

The authors declare no conflicts of interest regarding the publication of this paper.

${ }^{31}$ Ibid, p.19. 


\section{References}

Adewoye, O. (1977). The Judicial System in Southern Nigeria. Atlantic Highlands, NJ: Humanities Press Inc.

Akhigbe, E. E., Adekanle, A., Oamen, P. F., Tijani, A. A., Idahosa, M. F., \& Nwocha, M. E. (2014). 100 Years of Customary Law and Disputes Settlement in Nigeria: A Comment. In Proceedings of the 47th Annual Conference of the Nigerian Association of Law Teachers (pp. 471-488). Enugu: Kingdom Age Publications.

Garner, B. A. (1999). Black's Law Dictionary(7th Edition). St. Paul, MN: West Group.

Garner, B. A. (2009). Black's Law Dictionary(9th Edition). Dallas: West Publishing Co.

Igwe, I. O. (2019). Legal Practitioners in Public Service and the Unresolved Issue of Engaging in Private Legal Practice: An Appraisal. Law \& Justice Dispensation for Social Progress and Sustainable Development; a Festschrift in Honour of Hon. Justice Eze $U d u$. Abakaliki: Faculty of Law, Ebonyi State University.

Magaji, H. S. (2016). A Legal Analysis of ADR and the Civil Justice System in Nigeria. In Rule of Law, Governance Dispute Resolution and Contemporary Legal Issues in Nigeria (pp. 715-728). Zaria: ABU Press.

Mbiti, J. S. (1969). African Religion and Philosophy. London: Heinemann.

Obilade, A. O. (1979). Nigerian Legal System. Ibadan: Spectrum Law Publishing.

Okafor, I. A. et al. (2018). Avoiding Conflict Escalation and Total Implosion. Alternative Dispute Resolution Law Journal, 2, 45-82.

Onyeozili, E. C., \& Ebbe, O. N. I. (2012). Social Control in Precolonial Igboland of Nigeria. African Journal of Criminology and Justice Studies: AJCJS, 6, 29-43.

Theresa, A. A. (2014). Methods of Conflict Resolution in African Traditional Society. African Research Review: An International Multidisciplinary Journal, 8, 138-157.

https://doi.org/10.4314/afrrev.v8i2.9 